\title{
Effects of Plant Growth Regulators on in-vitro regeneration of a potential medicinal plant -Scilla hyacinthina (Roth.)J.F. Macbr
}

\author{
K. Kamaleswari, V. Nandagopalan, A. Lakshmi Prabha ${ }^{1}$ \\ PG \& Research Department of Botany, National College, Tiruchirappalli, Tamilnadu, India. \\ ${ }^{1}$ Department of Plant Sciences, Bharathidasan University, Tiruchirappalli, Tamilnadu, India.
}

\begin{tabular}{l} 
ARTICLE INFO \\
\hline Article history: \\
Received on: $05 / 11 / 2015$ \\
Revised on: 19/12/2015 \\
Accepted on: 27/12/2015 \\
Available online: 19/02/2016 \\
\hline Key words: \\
Scilla hyacinthina, TDZ, \\
IAA, Bulb scale, Scale leaf, \\
Microproagation. \\
\hline
\end{tabular}

\section{INTRODUCTION}

Scilla hyacinthina (Roth.)J.F. Macbr (Liliaceae) is an ephemeral grasses on the floor of scrub, located in India and some Asian countries[1]. The leaves are simple, oblong, succulent with purplish on the upper surface of leaves. The plant produce flush of white inflorescence and perennial tunicated bulb, bulb range from 10-14gm [2]. The plant bulb is used as anthelmintic, cardiac stimulant, digestive, diuretic, emmenagogue and expectoram [3]. It's also used in asthma, cough, bronchitis, paralytic attacks, ailments of the hearts, calculous affection, rheumatism and skin disease. The bulb paste to cure wounds and join the broken bone. The plant have major amount of carbohydrate and secondary metabolites such as alkaloids, flavonoids, saponins [4].Plant tissue culture is a rapid and regeneration of novel hybrid and large numbers of identical individuals, disease or pest resistant varieties, thus indirectly increasing the crop yield. Plant species are poor seed germination, frequency of seedling death and environmental challenges such as habitat destruction and illegal and indiscriminate collection [5]. Scilla, a monocotyledonous species

* Corresponding Author

Email: k.kamaleswari09@gmail.com belonging to the liliaceae, is one of the most important medicinal plants, mainly because of its pharmacological properties and attractive flowers. The continuous improvement of specific characters, such as flower colour morphology, longevity and size is essential for successful commercial application of any variety. Conventional breeding is the Scilla hampered by its heterozygous state and self- incomparability among the species of the different groups. The members of liliaceae have long been known as an amenable species, which adapt easily to most tissue culture techniques. Plant regeneration via organogenesisis easily achieved from a vast array of explants ranging from flower organs to bulb scales [6,] [7]. Non-conventional breeding methods offer new promising strategies for the improvement of crop but these techniques require a reproducible in vitro regeneration protocol.

Meristems is considered to be one of the most promising ways for plant regeneration and it's true type of selected variety also. Such individuals are genetically similar showing the same agronomic characteristics [8]. However, a major difficulty in this plants, just grow up after the rain fall and seed not fertility. Due to above the reason for plant propagated by in vitro technique. In this technique, produce more plantlets from piece of parts and disease free plants. An in vitro method has been successfully propagated for example species from a leaf 3 (anther) [9]. In the present studies to investigate of Scilla hyacinthina using different explants. 


\section{MATERIALS AND METHODS}

The fresh bulb materials of Scilla hyacinthina (Fig. 1) was collected from Bharathidasan University, Tiruchirappalli, Tamil Nadu, India. The collected samples were authenticated by Dr. V. Nanadagopalan, Associate Professor, PG \& Research Department of Botany, National College, Tiruchirappalli, Tamilnadu and a voucher specimen was deposited at Department of Botany, National College, and Tiruchirappalli.

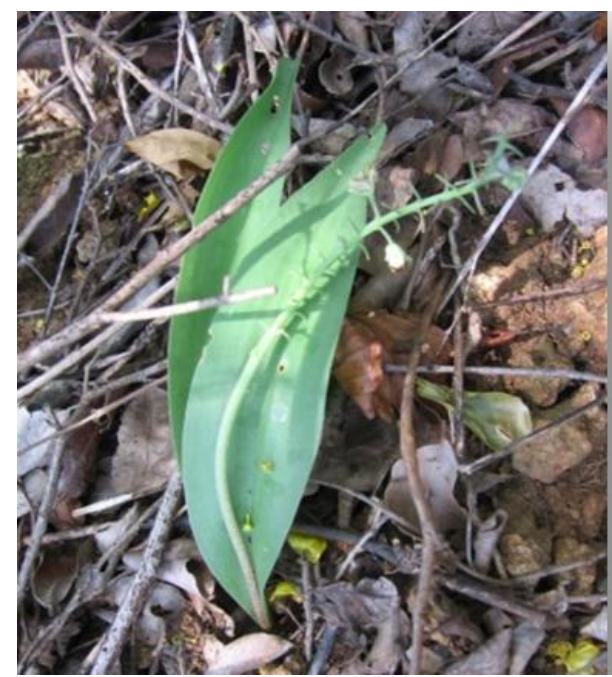

Fig. 1: Natural Habitat.

The explants were washed with running tap water for $2 \mathrm{~h}$, followed by teepol solution for 10min and rinsed for 3 times in distilled water. Whereas, $0.1 \% \mathrm{Hgcl}_{2}$ for $3 \mathrm{~min}$ and with $70 \%$ ethanol solution for 5 times. Then, these explants were rinsed for 5 min in sterile distilled water. MS medium supplemented with different hormones of BAP, TDZ, KIN, IBA\&IAA.

All the in vitro cultures were placed in the culture room maintained at $25 \pm 2{ }^{\circ} \mathrm{C}$ under continuous photoperiod with a photosynthetic photon flux density (PPFD) of $45 \mu \mathrm{mol} \mathrm{m}-2 \mathrm{~s}-1$ provided by cool white fluorescent lamps. The $\mathrm{pH}$ of all the media was adjusted to $5.7-5.8$ before autoclaving at $121{ }^{\circ} \mathrm{C}$ for $13 \mathrm{~min}$ under a pressure of $1.05 \mathrm{~kg} \mathrm{~cm}-2$.

\section{RESULTS}

The fresh plant materials were collected from field grown and these plant materials were used for culture on MS medium supplemented with various concentrations of BAP, TDZ \& KIN. During the study period, bacterial and fungal contaminations were observed on bulbs scale explants and these contaminants were eliminated by fungicide (Bavastin). For the initial time of culture, the explants were kept in dark condition for resting time.

The multiple shoot was observed in high concentration of $2.0 \mathrm{mg} / \mathrm{L}^{-1}$ BAP and TDZ at 45 day of culture (Table 1; Fig. 2a). Cytokinin concentration gradually induced multiple shoot regeneration from bulb scale and leaf scale explants.
Highest multiple shoot were observed at $2.0 \mathrm{mg} / \mathrm{l}^{-1}$ at BAP and TDZ in 12.7 $\pm 1.0,13.2 \pm 1.9$ and, $12.5 \pm 1.6,13.4 \pm 1.7$ from bulbs scale and scale leaf explants, respectively. The control plants (without PGR) were no shoot regeneration response from both the explants. KIN were also exhibited highest shoot regeneration from scale leaf explants.

The shoot were excised and inoculated on MS medium supplemented with various concentrations of IBA and IAA for induction of root regeneration.

Table 1: Effect of different concentration of BAP, TDZ and KIN on direct shoot formation from bulb scale and scale leaves explants of Scilla hyacinthina.

\begin{tabular}{ccccc}
\hline S.No & \multirow{2}{*}{$\begin{array}{c}\text { Hormones } \\
\text { Concentration (in mg/L) }\end{array}$} & \multicolumn{2}{c}{ Number of shoot } \\
\cline { 3 - 5 } 1 & Control & & - & Bcale leaves \\
\hline 2 & & 0.5 & $4.5 \pm 1.0$ & - \\
3 & & 1.0 & $6.3 \pm 1.5$ & $1.9 \pm 0.8$ \\
4 & BAP & 1.5 & $7.5 \pm 1.0$ & $2.8 \pm 0.7$ \\
5 & & 2.0 & $\mathbf{1 2 . 7} \pm \mathbf{1 . 8}$ & $\mathbf{1 3 . 4 \pm 1 . 7}$ \\
6 & & 2.5 & $5.5 \pm 1.0$ & $6.6 \pm 1.0$ \\
\hline 7 & & 0.5 & $3.1 \pm 0.8$ & $1.0 \pm 1.0$ \\
8 & & 1.0 & $5.7 \pm 1.0$ & $3.5 \pm 0.8$ \\
9 & TDZ & 1.5 & $7.7 \pm 1.5$ & $7.1 \pm 1.1$ \\
10 & & 2.0 & $\mathbf{1 3 . 2} \pm \mathbf{1 . 9}$ & $\mathbf{1 2 . 5} \pm \mathbf{1 . 6}$ \\
11 & & 2.5 & $6.7 \pm 1.1$ & $7.8 \pm 1.0$ \\
\hline 12 & & 0.5 & $2.3 \pm 1.1$ & $1.1 \pm 0.7$ \\
13 & & 1.0 & $3.4 \pm 1.0$ & $3.9 \pm 1.1$ \\
14 & KIN & 1.5 & $\mathbf{6 . 9} \pm \mathbf{1 . 1}$ & $\mathbf{1 2 . 6} \pm \mathbf{1 . 5}$ \\
15 & & 2.0 & $5.5 \pm 1.0$ & $8.6 \pm 0.9$ \\
16 & & 2.5 & $4.3 \pm 0.9$ & $5.6 \pm 1.1$ \\
\hline
\end{tabular}

No roots were observed without hormones. The highest number of roots was observed at $1.5 \mathrm{mg} / \mathrm{L}^{-1}$ of IAA $(7.3 \pm 6.9)$ form bulb scale explants. IAA was more efficient root regeneration while compared with IBA (Table-2; Fig. 2b).

Table 2: Effect of different combinations of IBA and IAA on root formation of bulb scale and scale leaf explants of Scilla hyacinthina

\begin{tabular}{|c|c|c|c|c|}
\hline \multirow[t]{2}{*}{ S.NO } & \multirow{2}{*}{\multicolumn{2}{|c|}{$\begin{array}{c}\text { Hormones } \\
\text { Concentration (in } \mathrm{mg} / \mathrm{L} \text { ) }\end{array}$}} & \multicolumn{2}{|c|}{ Number of roots } \\
\hline & & & Bulb scale & Scale leaf \\
\hline 1 & Control & & - & \\
\hline 2 & & 0.5 & $1.0 \pm 0.4$ & $0.6 \pm 0.5$ \\
\hline 3 & IBA & 1.0 & $4.7 \pm 0.7$ & $1.8 \pm 0.7$ \\
\hline 4 & & 1.5 & $7.3 \pm 0.9$ & $1.8 \pm 0.7$ \\
\hline 5 & & 0.5 & $2.6 \pm 0.2$ & $2.1 \pm 0.6$ \\
\hline 6 & IAA & 1.0 & $4.6 \pm 0.3$ & $3.7 \pm 1.1$ \\
\hline 7 & & 1.5 & $7.6 \pm 1.8$ & $6.5 \pm 0.2$ \\
\hline
\end{tabular}

Table 3: Different concentration of $\mathrm{GA}_{3}$ for shoots elongation of Scilla hyacinthina

\begin{tabular}{lccc}
\hline S.NO & \multicolumn{2}{c}{$\begin{array}{c}\text { Hormones } \\
\text { Concentration (in mg/L) }\end{array}$} & Shoot length (in cm) \\
\hline 1 & Control & 0.5 & - \\
\hline 2 & & 1.0 & $2.6 \pm 0.2$ \\
3 & & 1.5 & $4.6 \pm 0.3$ \\
4 & $\mathrm{GA}_{3}$ & 2.0 & $6.5 \pm 0.2$ \\
5 & & 2.5 & $5.3 \pm 0.1$ \\
6 & & & $4.6 \pm 0.1$ \\
\hline
\end{tabular}

$\mathrm{GA}_{3}$ were used for shoot elongation of plantlet, it's $1.5 \mathrm{mg} / \mathrm{L}^{-1}$ of $\mathrm{GA}_{3}$ showed highest results (Table 3; Fig. 2c \& d). 

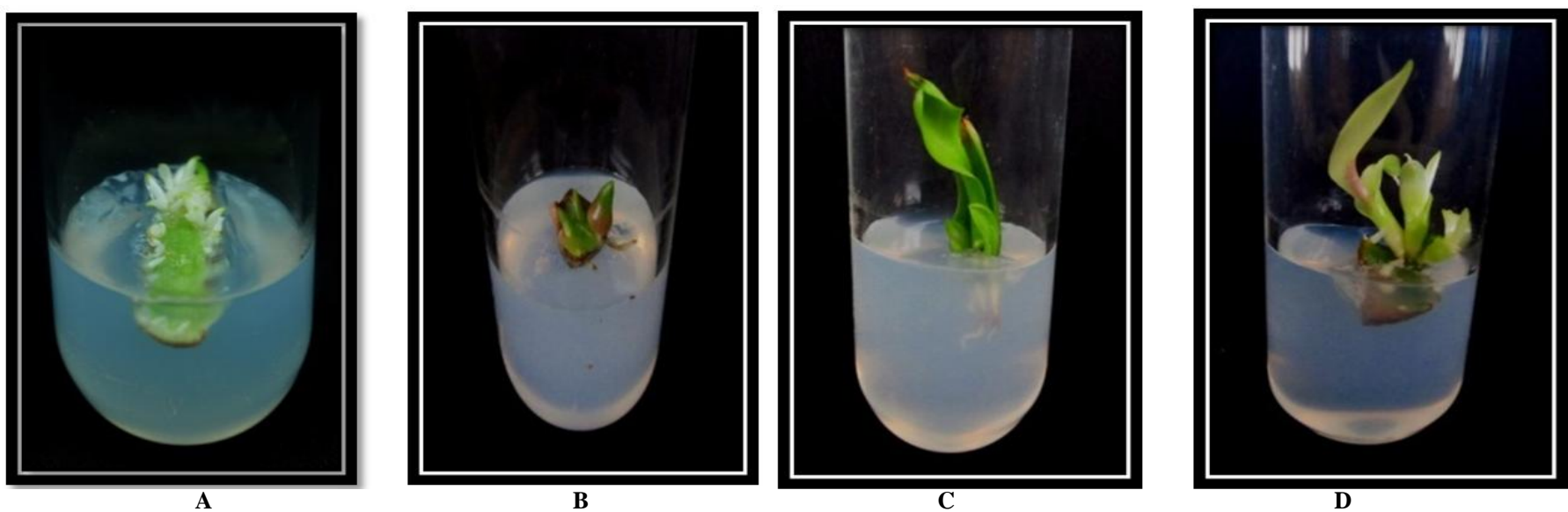

Fig. 2: Micropropagation studies on Scilla hyacinthina a. Initial stage of bulblet production from leaf scale explants, b. Root formation from bulblet on MS medium amended with IAA, c. Elongated shoots with many scale leaves, d. Formation of bulb as well as root.

\section{DISCUSSION}

The natural reproduction of seeds was more unfertile on Scilla hyacinthina. The bacterial and fungal contamination was observed on the bulb scale explants during study period. The bulb explant is often associated with heavy bacterial and fungal contamination [10], [11]. It is more difficult to large scale multiplication of these plants. There is urgent need to develop alternate method for production of without microbial contamination free plants. Plant tissue culture techniques are recalcitrant crops, especially monocotyledonous species and grass species. Previous studies reported that darkness to stimulate more direct shoot production than light condition [12] [13].

The effect of light can be interpreted as acting on metabolism and sugar uptake [14]. Bulb scales were most commonly used for in vitro micropropagation of geophytes. In the present work, bulb scale and scale leaf explants of S. hyacinthina were cultured on MS medium supplemented with different concentration of BAP, KIN and TDZ for shoot induction of explant. The highest concentration of BAP and TDZ shows generally increased the bulblet production than KIN. Similarly, stern Bergia fischerina of TDZ were produced several shoot formation from bulb scale and immature embryo explants [15]. Recently, Uranbay, [16] observed that BAP, KIN and 2iP were favorable bulblet production on 2-4 bulb scale of Muscari aucheri. Previous reports that observed cut treatment of bulb scale base explant of Hippeastrum to stimulate bulblet production [17]. In the present study, IAA was more efficient in promoting root formation than IBA. It has been described that IAA improve the number and quality of root in several species because it stimulates the cellular division of radial primordium, promotes the synthesis of specific proteins, and increases the sugar release into phloem [18]. In conclusion, the micropropagation protocol reported here was characterized with a rapid proliferation of shoots, easy rooting of the micro-shoots were easily developed. This is highly advantageous for the production of uniform source of selected potential medicinal plant for a range of further biotechnological applications.

\section{REFERENCES}

1. Mathew KM. The flora of tamilnadu Carnatic, part three, monocoteledons, India. 1983; 1646-1647.

2. Ghurde OM and Malode SN. Phytochemical screening and assessment of biomolecules compounds in Scilla hyacinthina (Roth) Macbr. Bulb. J.GlobalBiosci. 2014; 3(5): 866-871.

3. Sudhersen $\mathrm{C}$ and Padmanabhan D. In vitro propagation of Scilla hyacinthina (Roth.) Macbr. Curr. Sc. 1993; 64: 710

4. Akindel AJ and Adeyemi OO. Antinflammatoryactivity of the aqueous leaf extract of Byrsocarpuscoccineus. Fitoterapia. 2007; 78: 25-28.

5. Anis and Faisal. In vitro regeneration and mass multiplication of Psoraleacorylifolia - An endangered medicinal plant. Ind. J. Biotech. 2005; 4:261-264

6. Gupta P, Sharma AK and Chartuvedi HC. Multiplication of Liliumlongiflorum thumb. By aseptic culture of bulb scale. Ind.J.Exp.Biol. 1978; 16940-942.

7. Nhut DT, Le BV, Fukai S, Tanak M and VanTT. Effectsof activated charcoal,explant size, explant position and sucrose concentration on plant and shoot regeneration of Longiflorum via young stem. Plant Growth Reg. 2001; 33: 5965.

8. Wala BB and Jarai TY. Micropropagation of an endangered medicinal plant CurculigoorchioidsGaertn. Pl. Tissue cul. 2003; 13(1): 13-19.

9. Chakravarthy B and Sen S.1 Regeneration through somatic embryogenesis from anther explants of Scillaindica (Roxb.) Baker. Plant cell tissue and org cult.1989; 19:71-75.

10. Langens -Gerrits M, Albers $M$ and De klerkGJ,. Hot water treatment before tissue culture reduce initial contamination in lilium and Acer. Plant cell tissue and org cult 1998; 52:75-77.

11. Ziv M, Lilienkipnis $H$. Bud regeneration from inflorescence explant for rapid propagation of geophytes. In vitro Pl.Cell Report. 2000; 19:845-850.

12. Lin YS and Kwan SH. Recent advances of in vitro embryogenesis of monocotyledon and dicotyledon embryogenesis. 2012; 269-296. 
13. Mokhtari A, Alizadeh H, Samad YB, Omidi M, Otroshy M and Moeini Z. Effect of plant growth regulators on direct shoot regeneration of wheat immature embryonic explants. J. Agri. Eng. Biotech. 2013; 3:74-80.

14. Alizadeh H, Naghavi MR, Omidi M and Saatian B. Effect of plant growth regulation on direct shoot regeneration of wheat (Triticumaestivum). 2004; Aus.Agrono. Conf.

15. Mirici S, Parmaksiz I, Ozcan S, Sancakc, Uranbey S, Sarihan OE, Gumuscu A, GurbuzB,andArslan N. Efficient in vitro bulblet regeneration from immature embryos of endanged Sternbergia fischeriana. Plant cell tissue and org cult. 2005; 80: 239-246.

16. UranbeyS. Stimulating effects of different basal media and cytokinine types on regeneration of endemic and endanged Muscariaucheri. Arch Biol. Sci. Belgrade. 2010; 62(3):663-667.

17. Yanagawa $\mathrm{T}$ and Osaki Y.In vitro propagation of bulblets and elimination of viruses by bulb scale culture of Hippeastrumhybridum bulbs. Pl.Tissuecul. 1996; 13(2): 147-152.

18. Wilson PJ. The concept of a limiting rooting morphogen in woody stem cuttings. J. Hortic. Sci.1994;69:591-600.

\section{How to cite this article:}

Kamaleswari K, Nandagopalan V, Prabha AL. Effects of Plant Growth Regulators on in-vitro regeneration of a potential medicinal plant-Scilla hyacinthina (Roth.)J.F. Macbr. J App Biol Biotech. 2016; 4 (01): 043-046. DOI: 10.7324/JABB.2016.40108 